\title{
PLACES AND FUNCTIONS OF CIVIL PROCEDURAL LEGAL RELATIONS IN THE MECHANISM OF CIVIL PROCESSING REGULATION
}

\section{Didenko L. V.}

\section{INTRODUCTION}

The study of various theoretical aspects of civil procedural relations has always been the focus of procedural scientists. For many years, since the Soviet period, scientists have carried out both comprehensive studies of the theory of civil procedural relations, and studied the individual issues of nature and characteristics of the elements of their structure (subject composition, content, object). However, not many scholars have conducted the analysis of civil procedural relations as elements of civil procedural regulation today.

Therefore, the further development of civil procedural relations requires not only the general theoretical establishment of its essence, but also the definition of a role in the mechanism of civil procedural regulation. Such a study will also reflect the state and problems of the development of modern theory of civil procedural legal relations, since being the main way of realizing the rights and obligations of participants in civil proceedings, at the same time are an element of a much more complex formation - the mechanism of regulation. Therefore, much attention should be paid to the study of the place and functions of civil procedural relations in the mechanism of civil procedural regulation and their interaction with other constituent elements.

\section{The essence of the mechanism of civil procedural regulation}

In the general theoretical aspect, the "mechanism" is defined in the Great Interpretive Dictionary of Modern Ukrainian as an internal structure, a system of anything. That is, from a semantic point of view, this term means a set of interrelated elements. Therefore, the study of the structural parts of any mechanism should involve establishing both their place in such a system and their role in its functioning. Given that mechanism is a term characteristic of a number of spheres, it is important to analyze this concept precisely in the context of legal science.

Analyzing the views of scientists on the definition of the concept of "mechanism of legal regulation", let us note that the vast majority of them primarily operate with the definition proposed by S.S. Alekseev, since it was 
this researcher who first introduced it into scientific circulation. From the point of view of the scientist, the mechanism of legal regulation is taken in unity by a set of legal means by which legal influence on social relations is ensured. The structure of this mechanism is a set of means of legal influence, namely, such legal phenomena that "work" in the legal mediation of social relations. From this definition we can draw the following conclusions about the essence of the mechanism of legal regulation: 1) the mechanism of legal regulation consists of elements (legal remedies), which are considered above all in unity (act in a well-established and permanent relationship); 2) the purpose of the mechanism of legal regulation is to have a legal impact on public relations. We consider such a definition quite acceptable, given that it clearly reveals the essence of the mechanism, establishes its elemental composition and the specificity of the relationships between the elements. In addition, the disclosure of the essence of the mechanism in this way demonstrates that the term is indeed appropriate to use not only in the technical sciences, but also in the context of legal science.

With respect to the more modern views prevailing in domestic legal doctrine, let us note the point of view of A.F. The steed, which defines the mechanism of legal regulation as the process of transition of the normativity of law into the ordering of public relations, which is carried out by the subjects of legal regulation through the system of legal means, methods and forms in order to satisfy the public and private interests of participants of public relations, ensuring law and order.

Already from the list of features of the legal regulation mechanism taken into account by the researcher, we can conclude that this position is much more detailed. In particular, the researcher clearly establishes the participation of the subjects in the functioning of the mechanisms, identifies the tools for its implementation, draws attention to the systematic interaction of elements. Therefore, in general, we also consider this position to be sufficiently successful to form an understanding of the essence of the mechanisms of legal regulation.

Other positions of scientists are less perfect in this aspect. For example, S.T. Goncharuk, by the concept of the mechanism of legal regulation, understands the system of legal elements through which the legal regulation (ordering) of social relations is carried out ${ }^{1}$. Thus, the main provisions of this definition are: 1) the mechanism of legal regulation is explained as a system of legal elements; 2) the purpose of the mechanism of legal regulation is the legal regulation (ordering) of social relations.Such a position actually

\footnotetext{
${ }^{1}$ Гончарук С. Т. Адміністративне право України : навч. посіб. К. : Генеза, 2000.
} 
duplicates the point of view of S.S. But in general, it is not characterized by controversial elements or formulations.

Therefore, in general, the analyzed positions indicate that in legal science there is a unity of positions on the interpretation of the concept of "mechanism". In essence, the main model is the position of SS. Alekseeva ${ }^{2}$, which has been repelledby a number of scientists, but some researchers, including A.F. Horse Rider, significantly expand the essence of this concept. A common understanding is the interpretation of the mechanism of legal regulation as a system of legal means, methods and forms, which are its elements, which have a positive effect on social relations in order to regulate and regulate them.These elements are considered in unity, that is, acted in a smooth and constant manner. As a result of the mechanism of legal regulation, its subjects embody legal means, methods and forms, which allows to satisfy the public and private interests of participants in public relations and to ensure law and order.

Therefore, the main purpose of the mechanism of legal regulation is to give the relations of the subjects of normativity and satisfaction of interests of such persons. In general, the elements of the mechanism of legal regulation include legal remedies, methods and forms. Therefore, let us conclude that the legal nature of the mechanism of civil procedural regulation is based on a well-defined set of elements combined by interaction and common purpose.

Before moving on to the analysis of the constituent elements of the mechanism of civil procedural regulation, we consider it necessary to specify what is meant by this concept. S.V. Kymchinskaya defines the mechanism of legal regulation of civil procedural relations as a systematic set of complex, mutually agreed procedural legal means by which the state ensures the effective influence of civil procedural law on those legal relations that arise, change and terminate in civil proceedings. In general, such a definition is fully consistent with the conclusions we have drawn earlier in this paper, since the essence of the mechanism of legal regulation of civil procedural relations according to such a concept is fully consistent with the essence of the mechanism of legal regulation in general, but with sectoral features. Thus, an understanding of the mechanism of legal regulation of civil procedural relations can be expressed in the following provisions: 1) the mechanism is a set of complex, interdependent procedural remedies; 2) these elements are characterized by systemic and interdependent features, that is, they are interconnected, form a single whole,

${ }^{2}$ Цивільний процес України : навчальний посібник / за ред. Ю. С. Червоного. К., 2006. 
united by a common purpose; 3) elements of the mechanism of legal regulation of civil procedural relations are a state instrument by which the effective influence of civil procedural law on civil procedural relations is ensured. That is, in general, this definition can be explained as being identical to general theoretical concepts, taking into account industry specificities.

A.L. Pascar, exploring the mechanism of civil procedural regulation, clarifies that it is an element of the mechanism of general state legal regulation, which takes effect in the event of obstacles to legal regulation. On the one hand, it is an element of the general mechanism of legal regulation, and on the other - it is a relatively separate system with its own content, structure and functions.In such methodological approaches, the mechanism of civil procedural regulation can be regarded as a complex system, characterized by the theoretical basis of the conclusions drawn in the general theory of law regarding the concept of legal regulation, so to define the concept of "mechanism of civil procedural regulation" should be based on the concept of "mechanism of civil procedural regulation" regulation".

Therefore, given that, in general, the concept of the mechanism of civil procedural regulation was not actually established in the legal doctrine, we formulate a corresponding definition on the basis of previous general theoretical studies, but taking into account industry specificities.

The mechanism of civil procedural regulation is a system of complex, interrelated and united by common purpose procedural remedies, methods and forms that operate in a well-established and in constant connection and functioning of which is connected with the legal influence of the state on civil legal relations. in order to satisfy the public and private interests of the participants and to organize them.

The features of the mechanism of civil procedural regulation can be distinguished in the light of previous research and analysis of scientific literature.

1) the mechanism of civil procedural regulation is systemic and interdependent;

2) the mechanism of civil procedural regulation is purposeful and effective;

3) the combination of unity and differentiation in the mechanism of civil procedural regulation;

4) the effect of the mechanism of civil procedural regulation extends exclusively to the relations which are the subject of legal regulation;

5) the decisive role of the court in the mechanism of civil procedural regulation. 
The mechanism of civil procedural regulation as an element of the mechanism of legal regulation is also characterized by these features, however, taking into account the peculiarities of the field of civil procedural law, its subject and method.

The systemic nature is that the mechanism of civil procedural regulation consists of elements that interact in the process of legal regulation, ensuring the normal functioning of the whole mechanism of civil procedural law. These elements are interconnected, predictive of each other and act in concert. It should be noted that one of these elements is the civil procedural relationship.

The purposeful indication is that the mechanism of civil procedural regulation has the purpose of functioning, which, in particular, is set out in Article 2 of the CPC of Ukraine $^{3}$ - fair, impartial and timely consideration and resolution of civil cases in order to effectively protect violated, unrecognized or contested rights, freedoms or contested rights natural persons, rights and interests of legal entities, interests of the state. The "effectiveness" of the mechanism of civil procedural regulation in this context depends on whether the goals and objectives of justice have been achieved. Ineffective protection of violated, unrecognized or contested rights, freedoms or interests of individuals, rights and interests of legal entities, interests of the state indicates the need to improve civil procedural legislation.

The next feature is related to the legal nature of the mechanism of civil procedural regulation. As A. AL notes. Pascar, it has a dual nature, which is a combination of unity and differentiation' ${ }^{4}$. The unity of the mechanism of civil procedural regulation is ensured by establishing uniform procedures for the administration of justice in civil cases, defined by the law of the limits of judicial discretion, unity of civil procedural legislation, etc. It is worth agreeing with this explanation, and confirmation of it is the norms of the CPC of Ukraine. At the same time, a large number of civil cases, their differentiation by categories, by the specific circumstances of the case, the specifics of various situations that require individual settlement, the variety of legal facts, the differentiation of the procedure for opening proceedings in a particular case, etc. due to the peculiarities of the mechanism of civil procedural regulation. From all the above, we can conclude that there is a mechanism of civil procedural regulation of both unity and differentiation.

3 Цивільний процесуальний кодекс України: Закон України від 18.03.2004 № 1618-IV. Відомості Верховної Ради Украӥни. 2004. № 40-41, 42. Ст. 492.

4 Паскар А. Л. Роль механізму цивільного процесуального регулювання у забезпеченні ефективності цивільного судочинства. Приватне та публічне право. 2017. № 2. C. $37-40$. 
The character of the mechanism of civil procedural regulation extends exclusively to relations that are the subject of legal regulation and are derived from the nature of the investigated type of legal regulation mechanism. Since the mechanism of legal regulation includes a number of mechanisms that regulate certain spheres of public relations, the object of the mechanism of civil procedural regulation is exclusively public relations governed by the rules of civil procedural law. Therefore, the mechanism of civil procedural regulation includes the norms of the Constitution of Ukraine1, CPC of Ukraine 5 , Law of Ukraine "On Private International Law" of June 23, 2005 No. 2709-IV ${ }^{6}$, laws of Ukraine that determine the peculiarities of consideration of certain categories of cases, as well as international treaties the leniency of which is provided by the Verkhovna Rada of Ukraine, which respectively regulate public relations, which are the subject of its legal regulation.

The last feature highlighted by us is the decisive role of the court in the mechanism of civil procedural regulation. Although the rules of civil procedural law set out a number of rules for the functioning of the investigated mechanism (rules, principles, stages, requirements, etc.), however, only general limits of regulation are defined in this way. Accordingly, the main role in this process belongs to the court, which, in particular, in accordance with Article 12, paragraph 5 of the CPC of Ukraine $^{7}$, directs the course of the litigation, facilitates the settlement of the dispute by reaching an agreement between the parties, and clarifies their procedural rights and obligations, if necessary. consequences of committing or failing to act, contributes to the litigants in the exercise of their rights, prevents abuse of litigants' rights and takes measures to fulfill their responsibilities. That is, in the mechanism of civil procedural regulation, the general regulation is carried out by the rules of law, and the regulation taking into account the peculiarities of each specific relationship is exercised by the judge as their determining subject.

\section{Structural elements of the mechanism of civil procedural regulation}

Examining the mechanism of legal regulation, theorists of law point out that it has its own structure. However, as the analysis of the scientific literature indicates, the composition of the mechanism is not in all cases

5 Цивільний процесуальний кодекс України : Закон України від 18.03.2004 № 1618-IV. Відомості Верховної Ради України. 2004. № 40-41, 42. Ст. 492.

6 Про міжнародне приватне право: Закон України від 23.06.2005 № 2709-IV. Відомості Верховної Ради України. 2005. № 32. Ст. 422.

7 Цивільний процесуальний кодекс України : Закон України від 18.03.2004 № 1618-IV. Відомості Верховної Ради Украӥни. 2004. № 40-41, 42. Ст. 492. 
consistent between different researchers. Thus, one of the traditional concepts for this field is the concept proposed by S.S. Alekseev, who identified among the structural elements of the mechanism of legal regulation: 1) legal norms; 2) legal relations, namely: the subjective rights and legal obligations of the participant of such relations; 3) acts of realization of rights and obligations; 4) individual prescriptions and acts of application of law ${ }^{8}$. This concept is shared by other authors. Its structure is composed of elements that are at one level of legal regulation, exist and function only in interaction with others.

The concepts of scholars are quite common, distinguishing only three elements: 1) rules of law, which establish the general and legal binding rules of conduct for those participants in public relations who are in the field of legal regulation; 2) legal relations, which is the most important and necessary element of the real life of law; 3 ) acts of realization of legal rights and obligations - the actual behavior of the subjects of legal relations in the exercise of their rights and obligations. Let us pay attention to the following features of this position: first, its composition of elements fully corresponds to the elements proposed by S.S. Alexeev; secondly, legal relations stand out as the most important element among others; third, from the perspective of this researcher, individual prescriptions and acts of law are not part of the mechanism of legal regulation. In general terms, discussions are possible regarding the latter issue, however, in the field of civil legal regulation, the court is the decisive subject.

Accordingly, court decisions should be attributed to acts of law, because they are issued on the basis of legal facts and rules of law and determine the rights, obligations or measure of legal liability of individuals. Therefore, we conclude that with regard to the mechanism of civil procedural regulation, it is more appropriate to have a concept that provides for acts of law.

At the same time, some scholars distinguish another range of elements of the mechanism of legal regulation. For many scholars, the elemental structure of the mechanism of legal regulation of social relations is narrowed by the exclusion of elements of the legal relationship ${ }^{9}$, expanded by the introduction of additional components, such as legal consciousness, principles of law, legal facts, subjective legal rights and obligations, etc ${ }^{10}$. However, the previous concepts analyzed are still much more substantiated and more universal.

8 Алексеев С. С. Право: азбука - теория - философия. Опыт комплексного исследования. М.: Статут, 1999.

9 Лукьянова Е. Г. Механизм процессуального регулирования и его элементы. М. : Норма, 2001.

10 Заморська Л. І. Функції права: змістовно-теоретичний аналіз / Л. І. Заморська. Актуальні проблеми вітчизняної юриспруденції. 2015. Вип. 6. С. 3-9. 
From this we conclude that the only logical consistent theoretical construction of the mechanism of legal regulation in domestic theory is absent today. On this occasion S.V. Kimchynskaya notes that the presence of different approaches to the interpretation of the elementary set of the mechanism of legal regulation of social relations, on the one hand, indicates the complexity and multidimensionality of the phenomenon under study, and on the other hand - an indicator of the dynamics and development of legal science. In addition, let us look at another conclusion of the researcher despite the differences and contradictions of the concepts of the elemental composition of the mechanism of legal regulation, proposed by different scientists, the common feature of each selected component is that they are all either the result or the cause of human activity. Therefore, the researcher concludes that without the relevant subject of application, none of the elements can be implemented. With this in mind, the scientist proposes to supplement the list of elements of the mechanism of legal regulation of civil procedural relations with another element - the subject of legal realization, which in the aspect of the research institute is the court and other participants of the civil process ${ }^{11}$. Considering thatthe concept of SS is dominant in the national science. Alekseeva, let us conclude that the allocation of the elemental composition of the mechanism of civil procedural regulation should be made on the basis of its position, as well as the conclusions made by S.V. Kymchinskaya.

Therefore, we summarize the analysis performed by identifying the following elements of the civil procedural regulation mechanism, which are:

1) the subject of the right realization (above all the court, as well as the participants in the civil process);

2) rules of civil procedural law;

3) civil procedural legal relations;

4) acts of realization of rights and obligations (will of subjects of civil procedural relations);

5) acts of application of law (according to Article 258 of the CPC of Ukraine $^{12}$, judicial acts of application of law are decisions, decisions, decisions, court orders).

In the implementation of the mechanism of civil procedural regulation, the subject of legal realization is the element with which civil procedural relations are of primary importance, since the parties are an obligatory

11 Кімчинська С. В. Суб'єктний склад механізму цивільного процесуального регулювання. Науковий вісник Чернівецького національного університету. 2013. Вип. 714. С. 78-82.

12 Цивільний процесуальний кодекс України : Закон України від 18.03.2004 № 1618-IV. Відомості Верховної Ради Украӥни. 2004. № 40-41, 42. Ст. 492. 
element of any legal relationship. The substantive composition of the mechanism of civil procedural regulation has already been established by us in this work. It consists of the following elements:

1) parties to the case - parties (natural and legal persons as well as the state), third parties, in criminal proceedings the applicant and the debtor, in the cases of separate proceedings the parties to the proceedings are the applicants, bodies and persons to whom the law has the right to go to court for interests other persons (bodies of state power, bodies of local selfgovernment, Ombudsman of Ukraine), prosecutor, representatives;

2) other participants in the trial - Assistant Judge, Registrar, Attorney, Witness, Expert, Law Expert, Translator, Specialist;

3 ) the court as an indispensable participant in civil procedural legal relations - a judge alone; a collegiate court composed of one judge and two jurors; a three-judge panel of appeal judges; a panel of judges of the court of cassation of three or more odd judges; Grand Chamber of the Supreme Court.

Civil procedural relations and subjects of legal realization as elements of the mechanism of civil procedural regulation are interrelated, and their relationship is primarily that civil procedural relations arise in the course of consideration and settlement of a specific case due to the will of one of the parties. In this case, the participants in the case are involved in a voluntary or coercive mechanism, and the participation of the court and other participants in the trial is the realization of their right to work and duties.

In other words, the acts of realization of rights and duties as elements of the mechanism of civil procedural regulation are the will of the subjects of civil procedural relations, expressed in this context mainly in a documentary form, which consists in the exercise by such persons in accordance with the rules of civil procedural law of their capabilities, performance. obligations or compliance with injunctions that have legal consequences for them. Relation of the acts of realization of rights and obligations with the civil procedural obligations is first of all that they are the form according to which civil procedural relations arise or change.

Therefore, summarizing the study of the place of civil procedural relations in the mechanism of civil procedural regulation, we should draw the following conclusions: 1) civil procedural relations are an element of the mechanism of civil procedural regulation, without which its functioning is impossible; 2) civil procedural relations are related to other elements of the mechanism of civil procedural regulation as follows: a) the subject of legal proceedings is the element with which civil procedural relations are of primary importance, since the parties are an obligatory element of any legal relations; b) civil procedural relations arising in the course of consideration 
and settlement of a particular case are governed by the rules of civil procedural law; c) the connection between the acts of realization of rights and obligations as an element of the mechanism of civil procedural regulation with civil procedural relations is that they are the basis for their origin and change or termination; d) the acts of law are an element of the mechanism of civil procedural regulation, which causes the termination of civil procedural relations.

\section{Functions of civil procedural legal relations in the mechanism of civil procedural regulation}

The next question to be addressed is the function of civil procedural relations in the mechanism of civil procedural regulation. The concept of "function" in the theoretical sense is not exclusively legal. This term was first introduced into scientific circulation as mathematical, but later entered into legal terminological circulation.

The term "function of law" was first used in the nineteenth century in the work of German Roman law researcher R. Ehring, "The Spirit of Roman Law at Different Stages of Its Development," which argued that the function of law is its realization. Subsequently, this definition has undergone considerable transformation and refinement, but the main idea of the functions has been properly enshrined - functions are a form of influence of law. Subsequently, the issue of defining the functions of law was developed at the sectoral level, and new conceptual approaches to defining this concept emerged.

In encyclopedic sources, the concept of "function" is considered in two meanings: 1) as a phenomenon that depends on another phenomenon, acts as a form of its detection and changes in accordance with its changes; 2) as a job, a duty, a range of activities, etc. Of these two, the former is general and in no way related to legal theory. With regard to understanding a function as a phenomenon that is dependent on another phenomenon, acts as a form of its detection and changes according to its changes, then such a meaning can be correlated with the legal, if the term "phenomenon" means the concept of "right". In this case, the function is a phenomenon that depends on the law, acts as a form of its detection and changes according to its changes. Yes, indeed, the functions of civil procedural legal relations will change provided that changes are made to the existing civil procedural legislation, for example, the CPC of Ukraine.

Equally true is the assertion that function is a form of discovery of law, because by the use of functions, the effect of law is on certain legal relations. Therefore, we conclude that a general theoretical understanding of the 
concept of "function" may well underlie the special legal definitions. This is confirmed by the analysis of the scientific approaches of legal scholars.

Regarding the encyclopedic legal literature, in the Legal Encyclopedia, edited by Yu.S. Shemshchenk's functions are defined as "the directions or types of influence of law on social relations, by which the role and purpose of law in society and the state, its social value and the most important features are expressed"13. That is, characterizing the essence of functions, we should start from the following: 1) first of all, functions are the directions of influence of law, that is, how exactly law influences social relations; 2) the function expresses the role and purpose of law in society and the state, its social value and the most important features, namely: functions allow you to establish the role of law in regulating the relevant legal relations. In general, this approach is close to a theoretical understanding of the essence of functions from a legal point of view. Yes, functions are seen as directions or types of influence of law on public relations. That is, functions are indeed a manifestation of law that reflects its impact on public relations.

This understanding was formed in the classical theory of law, in which the authors at that time analyzed the concept of "function" in the context of the influence of law on the development of social relations. For example, Yu.G. Tkachenko viewed the functions of law as the specific role of law in organizing public relations ${ }^{14}$. This understanding is quite comparable to the understanding of the functions as directions of influence of law. That is, the influence of the right on social relations is exercised for the purpose of organizing them. The explanation of the essence of functions as a role of law is not quite accurate, but in general this model remains relevant to this day.

The notion of "function of civil procedural relations", as well as "function of legal relations", in general, are not characteristic of national science, so in formulating the appropriate definition, we will take the general theoretical concept, as well as formulated by us earlier definition of the concept of "civil procedural relations. Therefore, let us define the functions of civil procedural relations as the directions of influence of civil procedural law on public relations governed by the rules of civil procedural law arising in civil proceedings in order to ensure justice in the protection of violated, unrecognized or contested rights, freedoms or interests of physical persons, interests or interests persons, the interests of the state between the court as a compulsory subject, the persons involved in the case, and other participants

13 Юридична енциклопедія : в 6 т. / гол. ред.: Ю. С. Шемшученко, М. П. Зяблюк, В. Д. Горбатенко та ін. Т. 6: Т-Я. К. : Українська енциклопедія ім. М. П. Бажана, 2004.

14 Ткаченко Ю. Г. Методологические вопросы теории правоотношений. М. : Юридическая литература, 1980. 
in the civil process through which erred to the role and purpose of civil procedure law in society and the state, its social value and important features.

Thus, it has been established in the scientific literature that the problem of classification of functions of legal regulation is at the same time one of the essential problems of the theory of law. However, these functions are mainly regarded as subspecies of the regulatory function of law ${ }^{15}$. Thus, the regulatory function is one of the determining directions of the influence of law on social relations in the system of functions of law, and it can be defined as the direction of legal influence due to its social purpose, which is expressed in establishing positive rules of conduct, granting rights and imposing legal obligations on the sub of law. As it is noted in scientific works, the main forms in which the social function of the regulatory function, namely the regulation of social relations, manifests itself are: 1) whether it finds expression in the form of normative or enforceable acts; 2) whether it is carried out in general or specific legal relations; 3 ) whether it establishes the legal status, legal personality of citizens, or determines the competence of state bodies and legal entities ${ }^{16}$.

In general, there are three approaches to identifying sub-functions within a regulatory function within legal sources:

1. Selection of two elements - regulatory static and regulatory dynamic subfunctions;

2. Selection of three elements - regulatory static, regulatory dynamic subfunction and regulatory negative subfunction ${ }^{17}$;

3. Selection of a number of elements - for example, functions of ordering, guaranteeing, coordination and protection of interests, integrative, political, stabilizing, modeling, orienting, stimulating and limiting.

Of all these models, the first and the second are more traditional. Given that a negative subfunction of the regulatory function of legal regulation is to establish a prohibition of certain behavior, we note its inherent in civil procedural relations. Therefore, in the context of the topic of our study, a second model is more appropriate.

\footnotetext{
${ }^{15}$ Куракін О. М. Аналіз функцій правового регулювання в аспекті його ефективності. Науковий вісник “Держава та регіони”. 2016. № 2. С. 53-58.

${ }^{16}$ Тарахонич Т. І. Механізм дії права, механізм правового регулювання, механізм реалізації права: особливості взаємодії. Держава і право. Серія "Юридичні і політичні науки”. К. : Ін-т держави і права ім. В. М. Корецького НАН України, 2010. Вип. 50. C. $11-17$.

${ }^{17}$ Горшенев В. Н. Способы и организационные формы правового регулирования. М., 1972.
} 
Along with the regulatory function, traditionally, another function of law and legal relations - security. This opinion, in particular, is supported by Yu.S. Chervonyi, from which point of view, the protective function of civil procedural law is aimed at restoration of property and personal non-property rights, freedoms and legal interests of the subjects of law ${ }^{18}$. That is, the essence of this function lies in the fact that the subjects of civil procedural law enter into appropriate legal relations in order to restore property and personal non-property rights, freedoms and legitimate interests. Considering that civil procedural relations arise in civil proceedings for the purpose of ensuring justice in the protection of the violated, unrecognized or contested rights, freedoms or interests of individuals, rights and interests of legal entities, interests of the state, we conclude that they also exercise and protect.

On the other hand, the above list of functions does not take into account the specifics of civil procedural relations in the mechanism of civil procedural regulation. Therefore, we propose to distribute the functions of civil procedural legal relations in the mechanism of civil procedural regulation into general theoretical functions of civil procedural legal relations and special sectoral functions of civil procedural legal relations.

The general theoretical functions of civil procedural relations are related to the consolidation of existing civil procedural relations, the development of new ones, and the establishment of limits to the possible behavior of subjects. Special sectoral functions of civil procedural relations are aimed at providing the whole mechanism of civil procedural regulation, as well as regulating the behavior of participants in legal relations.

The general theoretical functions of civil procedural relations in the mechanism of civil procedural regulation are:

1) regulatory static function - is related to the consolidation of existing public relations;

2) regulatory dynamic function - related to the development of new social relations;

3) regulatory negative function - a ban on certain behavior is established $^{19}$;

4) security function - related to the restoration of property and personal non-property rights, freedoms and legitimate interests of legal entities ${ }^{20}$.

${ }^{18}$ Цивільний процес України : навчальний посібник / за ред. Ю. С. Червоного. К., 2006.

${ }^{19}$ Куракін О. М. Аналіз функцій правового регулювання в аспекті його ефективності. Науковий вісник “Держава та регіони”. 2016. № 2. С. 53-58.

${ }^{20}$ Цивільний процес України : навчальний посібник / за ред. Ю. С. Червоного. К., 2006. 
Special features of civil procedural legal relations in the mechanism of civil procedural regulation we propose to distinguish from the analysis of scientific literature. In this aspect, given the low level of attention of domestic researchers to this issue, let us first of all highlight the work of A.M. Pascar $^{21}$ and some law theorists9 whose work contributed to the selection of special sectoral functions of civil procedural relations in the mechanism of civil procedural regulation.

1) security function - the analysis of legal sources showed that the place of civil procedural relations in the mechanism of civil procedural regulation is not limited to the fact that they are an integral part of the latter;

2) nation-wide orientation function - in the general sense, the orientation function is that the subject, knowing the prescriptions of legal norms, himself builds his behavior in a lawful manner, which is the purpose of the state in determining patterns of lawful behavior;

3) individual orientation function - individual regulation is defined as the solution of specific problems based on the rules of law. S.S. Alexeyev ${ }^{22}$ explains individual regulation by the fact that no norm is able to cover the whole set of legal facts and to take into account all the peculiarities of situations that cause the law to be applied, and therefore it makes it necessary to allow the legislator to regulate legal relations by the subjects themselves.

That is, having only a national orientation function is not sufficient for a mechanism of civil procedural regulation, and the implementation of such provisions is important. The court, entering into the relevant legal relations, continues to regulate them with the help of acts of law. However, at the scientific level, it is noted that in the field of civil procedural law, legal regulation cannot begin to exert its influence without individual regulation, since it is the court that establishes the connection between the rule of law and the specific situation, thereby triggering the rules of civil procedural law.

\section{CONCLUSIONS}

Thus, having examined the place and functions of civil procedural legal relations in the mechanism of civil procedural regulation, it should be noted that this institute is one of the key for the whole system under study. On the

21 Паскар А. Л. Місце цивільних процесуальних правовідносин у механізмі цивільного процесуального регулювання. Науковий вісник Чернівецького університету. 2012. Вип. 618. С. 82-88.

22 Проблемы теории государства и права : допущено Министерством высшего и среднего специального образования СССР в качестве учебника для студентов вузов, обучающихся по специальности "Правоведение" / [C. С. Алексеев, И. Я. Дюрягин, В. Б. Исаков и др.] ; под ред. С. С. Алексеева. М. : Юрид. лит., 1987. 
one hand, it should be noted that each of the elements selected by us is mandatory for the mechanism, so the absence of any of them makes it impossible to operate. Civil procedural relationships, on the other hand, are the one component that brings together all the other elements around them. Therefore, when correlating civil procedural relations with other elements of the mechanism of civil procedural regulation, it is worth noting the close relationship of each of them, as well as the primary role of the investigated component.

\section{SUMMARY}

The article deals with the analysis of the place and functions of civil procedural relations. The author emphasizes that in the mechanism of civil procedural regulation can undergo significant changes both from the point of view of the organization (for example, by expanding the scope of civil jurisdiction), and from the point of view of changing the scope of rights and obligations of subjects of civil procedural regulation in the process of improvement relevant legal institutions.

The author examines the place and functions of civil procedural relations in the mechanism of civil procedural regulation. Many of the studies we analyzed were carried out many years ago, and the development of public relations and legislation in our country is permanent, which makes the actual implementation of this research.

The author analyzes the main feature of the functions and the general theoretical functions of civil procedural relations in the mechanism of civil procedural regulation. The author emphasizes the peculiarities of civil procedural relations in the mechanism of civil procedural regulation.

\section{REFERENCES}

1. Конституція України : Закон України від 28 черв. 1996 р. Відом. Верхов. Ради України. 1996. № 30. Ст. 141.

2. Цивільний процесуальний кодекс України : Закон України від 18.03.2004 № 1618-IV. Відомості Верховної Ради Украйни. 2004. № 40-41, 42. Ст. 492.

3. Про міжнародне приватне право : Закон України від 23.06.2005 № 2709-IV. Відомості Верховної Ради Украӥни. 2005. № 32. Ст. 422

4. Алексеев С. С. Право: азбука - теория - философия. Опыт комплексного исследования. М.: Статут, 1999. 712 с.

5. Великий тлумачний словник сучасної української мови (з дод. і допов.) / уклад. і голов. ред. В. Т. Бусел. К.; Ірпінь : ВТФ “Перун”, 2005. $1728 \mathrm{c}$. 
6. Гончарук С. Т. Адміністративне право України : навч. посіб. К. : Генеза, 2000. 240 c.

7. Горшенев В. Н. Способы и организационные формы правового регулирования. М., 1972. 153 с.

8. Діденко Л. В. Функції цивільних процесуальних відносин у механізмі цивільного процесуального регулювання. Науковий вісник публічного та приватного права: зб. наук. пр. Київ, 2017. Вип. 6. Т. 4. C. 39-45.

9. Загальна теорія держави і права : підручник для студентів юридичних вищих навчальних закладів / М. В. Цвік, О.В.Петришин, Л. В. Авраменко та ін.; за ред. д-ра юрид. наук, проф., акад. АПрН України М. В. Цвіка, д-ра юрид. наук, проф., акад. АПрН України О. В. Петришина. Харків : Право, 2009. 584 с.

10. Заморська Л. І. Функції права: змістовно-теоретичний аналіз / Л. І. Заморська. Актуальні проблеми вітчизняної юриспруденції. 2015. Вип. 6. С. 3-9.

11.Иеринг Р. Дух римского права на различных ступенях его развития / пер. с 3-го исправл. нем. изд. СПб. : Тип. В. Безобразова и Ко, 1875. Ч. 1. $321 \mathrm{c.}$

12. Кельман М. С., Мурашин О. Г. Загальна теорія держави і права : підручник. К. : Кондор, 2006. 477 с.

13. Кімчинська С. В. Суб'єктний склад механізму цивільного процесуального регулювання. Науковий вісник Чернівецького національного університету. 2013. Вип. 714. С. 78-82.

14. Куракін О. М. Аналіз функцій правового регулювання в аспекті його ефективності. Науковий вісник “Держава та регіони”. 2016. № 2. C. 53-58.

15. Лазарев В. В., Липень С. В. Теория государства и права : учебник. 3-е изд., перераб. и доп. М. : Спарк, 2004. 528 с.

16. Лукьянова Е. Г. Механизм процессуального регулирования и его элементы. М. : Норма, 2001. 106 с.

17. Паскар А. Л. Місце цивільних процесуальних правовідносин у механізмі цивільного процесуального регулювання. Науковий вісник Чернівецького університету. 2012. Вип. 618. С. 82-88.

18. Паскар А. Л. Роль механізму цивільного процесуального регулювання у забезпеченні ефективності цивільного судочинства. Приватне та публічне право. 2017. № 2. С. 37-40.

19.Проблемы теории государства и права : допущено Министерством высшего и среднего специального образования СССР в качестве учебника для студентов вузов, обучающихся по специальности "Правоведение" / [С. С. Алексеев, И. Я. Дюрягин, 
В. Б. Исаков и др.] ; под ред. С. С. Алексеева. М. : Юрид. лит., 1987. $448 \mathrm{c.}$

20. Скакун О. Ф. Теорія держави і права : підруч. Х. : Консум, 2008. $656 \mathrm{c}$.

21. Словник української мови : в 11 т. / за ред. І. К. Білодіда, А. А. Бурячок та ін. Т. 10. К. : Наукова думка, 1979. 657 с.

22. Тарахонич T. I. Механізм дії права, механізм правового регулювання, механізм реалізації права: особливості взаємодії. Держава і право. Серія “Юридичні $i$ політичні науки”. К. : Ін-т держави і права ім. В. М. Корецького НАН України, 2010. Вип. 50. C. 11-17.

23. Теория государства и права : учебник / под ред. С. С. Алексеева. М. : Норма, 2004. 496 c.

24. Ткаченко Ю. Г. Методологические вопросы теории правоотношений. М. : Юридическая литература, 1980. 176 с.

25. Цивільний процес України : навчальний посібник / за ред. Ю. С. Червоного. К., 2006. 392 с.

26. Юридична енциклопедія : в 6 т. / гол. ред.: Ю. С. Шемшученко, М. П. Зяблюк, В. Д. Горбатенко та ін. Т. 6: Т-Я. К. : Українська енциклопедія ім. М. П. Бажана, 2004. 768 с.

\section{Information about the author: Didenko L. V.,} $\mathrm{PhD}$, Associate Professor at the Department of Civil and Economic Law and Procedure, International Humanitarian University 33, Fontanska Road str., Odessa, 65009, Ukraine 